\title{
BioDinamica: a toolkit for analyses of biodiversity and biogeography on the Dinamica-EGO modelling platform
}

\author{
Ubirajara Oliveira ${ }^{\text {Corresp., } 1}{ }^{1}$, Britaldo Soares-Filho ${ }^{1}$, Rômulo Fernandes Machado Leitão ${ }^{1}$, Hermann Oliveira \\ Rodrigues $^{1}$ \\ ${ }^{1}$ Centro de Sensoriamento Remoto, Instituto de Geociências, Universidade Federal de Minas Gerais - UFMG, Belo Horizonte, Minas Gerais, Brazil \\ Corresponding Author: Ubirajara Oliveira \\ Email address: ubirajara@csr.ufmg.br
}

Biogeography and macroecology are at the heart of the debate on ecology and evolution. We have developed the BioDinamica package, a suite of user-friendly graphical programs for analysing spatial patterns of biogeography and macroecology. BioDinamica includes analyses of beta-diversity, species richness, endemicity, phylo-diversity, species distribution models, predictive models of biodiversity patterns, and several tools for spatial biodiversity analysis. BioDinamica consists of a sub-library of Dinamica-EGO operators developed by integrating EGO native functions with R scripts. The BioDinamica operators can be assembled to create complex analytical and simulation models through the EGO graphical programming interface. In addition, we make available "Wizard" tutorials for end users. BioDinamica can be downloaded free of charge from the Dinamica EGO submodel store. The tools made available in BioDinamica not only facilitate complex biodiversity analyses, they also help develop state-of-the-art spatial models for biogeography and macroecology studies. 


\title{
BioDinamica: a toolkit for analyses of biodiversity and biogeography on the Dinamica-EGO modelling platform
}

\author{
Ubirajara Oliveira ${ }^{1}$, Britaldo Soares-Filho ${ }^{1}$, Rômulo Fernandes Machado Leitão ${ }^{1}$, Hermann Oliveira \\ Rodrigues $^{1}$ \\ 1- Centro de Sensoriamento Remoto, Instituto de Geociências, Universidade Federal de Minas Gerais - \\ UFMG, Av. Antonio Carlos 6627, CEP 31270-901, Belo Horizonte, MG, Brasil.
}

\section{Abstract}

Biogeography and macroecology are at the heart of the debate on ecology and evolution. We have developed the BioDinamica package, a suite of user-friendly graphical programs for analysing spatial patterns of biogeography and macroecology. BioDinamica includes analyses of beta-diversity, species richness, endemicity, phylo-diversity, species distribution models, predictive models of biodiversity patterns, and several tools for spatial biodiversity analysis. BioDinamica consists of a sub-library of Dinamica-EGO operators developed by integrating EGO native functions with $\mathrm{R}$ scripts. The BioDinamica operators can be assembled to create complex analytical and simulation models through the EGO graphical programming interface. In addition, we make available "Wizard" tutorials for end users. BioDinamica can be downloaded free of charge from the Dinamica EGO submodel store. The tools made available in BioDinamica not only facilitate complex biodiversity analyses, they also help develop state-ofthe-art spatial models for biogeography and macroecology studies.

\section{Introduction}

Biogeographical and macroecological studies have multiplied largely over the last decade (Ladle et al., 2015). Proportionally, novel methods of analyses have also been developed. Many of these methods focus on spatial pattern representation, such as areas of endemism, species richness and beta-diversity (Vilhena \& Antonelli, 2015; Oliveira, Brescovit \& Santos, 2015), while others aim to predict these patterns (Graham \& Hijmans, 2006; Ferrier et al., 2007). Similarly, there has been an increasing number of studies including phylogenetic trees due to the growing availability of data (Hinchliff et al., 2015) and hence the possibility of testing explicit evolutionary components through biogeography analyses. As a result, biogeographical and macroecological methods that apply phylogenetic data to understand evolutionary geographical patterns have also multiplied, e.g. phylogenetic beta diversity, phylogenetic endemism and phylodiversity (Graham \& Fine, 2008; Donnellan \& Cook, 2009). In addition to biogeographical and macroecological analyses, all these novel methods are extremely important for conservation studies (Whittaker et al., 2005; Mcgoogan et al., 2007; Fenker et al., 2014).

There are few computer programs that make available in a single environment several analytical tools for biogeography and macroecology analyses - e.g. Passage (Rosenberg \& Anderson, 2011). Even this software has only few available analyses, yet they do not directly involve maps. Software, like DIVA-GIS (R.J. Hijmans L. Guarino \& Rojas, 2001), that perform biogeographic analyses using maps remain rare. However, even DIVA-GIS package contains only a very limited set of functions. Most of the tools available for biogeography analyses are only present in R packages, which are difficult to be used by biologists or other specialists who do not master programming language. Friendly graphical interface programs are 
uncommon, and when available are limited to just a few specific analyses - e.g. for species distribution models (SDM) Open Modeller (Souza Muñoz et al., 2011), Maxent (Phillips, Dudík, \& Schapire, 2004), Modeco (Guo \& Liu, 2010) and for biogeographical analyses PASSAGE (Rosenberg \& Anderson, 2011) and DIVA-GIS (R.J. Hijmans L. Guarino \& Rojas, 2001).

Biogeography software to date do not encompass a wide set of relevant analyses. Some promising methods, such as Generalized Dissimilarity Model (GDM), for instance, (Ferrier, Manion, Elith, \& Richardson, 2007) is eleven years old, but still little used (e.g. Ferrier, Harwood, Williams, Dunlop, \& Ferrier, 2012; Carnaval et al., 2014; Rosauer et al., 2014), possibly because it is only available as a R package. Similarly, other methods, such as the Geographical Interpolation of Endemism - GIE (Oliveira, Brescovit, \& Santos, 2015), which identifies areas of endemism without the use of grid cells as sample units, have been barely used due to the absence of a friendly software-performing GIE requires a series of GIS standalone procedures. Even widely used methods, such as SDMs, have their functions dispersed in several $\mathrm{R}$ packages and various software. Moreover, processes required for modelling species distribution are often not available in SDM software, requiring the use of GIS and statistical software to perform a thorough analysis.

Given the growing interest in spatial analyses in biogeographic and macroecology, we have developed a set of user-friendly tools embedded in the Dinamica-EGO software (Soares-Filho et al., 2013). DinamicaEGO is a freeware (www.dinamicaego.com) for developing from simple to complex spatially explicit models, which has been applied to many environmental studies (see https://csr.ufmg.br/dinamica/publications). We coupled a series of Dinamica EGO operators with R code (https://www.r-project.org) to build more than 50 biogeographic and macroecological analytical functions (Table 1), all of which with a user-friendly graphical interface. These functions are stored in a sub library of Dinamica-EGO, named BioDinamica, thus allowing the user to build complex biodiversity models in a single integrated environment. In addition to the direct application of these tools to biogeography, biodiversity and macroecology (e.g. phylodiversity, species distribution models, phylogenetic endemism, areas of endemism, etc), some of the available functions, such as generalized linear models (GLM), geographically weighted regression (GWR), and raster PCA projection (principal components analysis) are also applicable to several other study fields. BioDinamica takes advantage of Dinamica EGO high performance computing, nonetheless, requiring computer resources as those available on common laptop computers, such as a minimum of $4 \mathrm{~GB}$ of RAM and Windows or Linux operating system.

\section{Survey Methodology}

\section{Overview}

Functions provided include areas of endemism, species richness, phylodiversity, beta-diversity endemicity, species distribution models (SDMs), beta-diversity predictive models (GDM), interpolators, spatial analysis of ordination (PCA, PCR, NMDS), spatial statistical analysis (GLM, LM) and tools for conservation analysis, such as the Minimum Convex Hull (Table 1). All functions include R codes as well as specific R packages which are enveloped by the Dinamica EGO Operator called "Calculate R Expression". Although functions can be broken up for inspection, reuse, or further development, the users do not need to deal with the R code; instead they only need to configure or connect the parameters of these new hybrid operators by visually editing their inputs and outputs ports. 
80

81

82

83

84

85

86

87

88

89

90

91

92

93

94

95

96

97

98

99

100

101

102

103

104

105

106

107

108

109

110

111

112

113

114

115

116

117

\section{8}

119

120

121

To facilitate the use of Biodinamica functions, we have standardized the operators' inputs (Figure 1). Thus, functions for analyses of spatial diversity patterns (species richness, beta-diversity, areas of endemism, etc.) have as input a table in csv format with points of occurrence of species in three columns: $\mathrm{sp}, \mathrm{x}$ and $y$ (species name, longitude and latitude in decimal degrees) and a mask of the study area in shapefile format (Figure 1). Analyses using phylogenetic data (phylodiversity, phylogenetic beta-diversity, phylogeneticGDM, etc) include a phylogenetic tree in newick format, along with the inputs for analyses of diversity pattern (species points and mask, as mentioned above). Analyses that rely on predictor variables (such as GDM, SDMs, interpolation and prediction by GLM, LM, SAR) use as input raster files only in the GeoTiff format. Spatial interpolation needs only a table in csv format with input variable values and respective geographic coordinates (columns: dependent, $x$ and $y$ ). Predictor-based interpolations (GLM, LM, GWR, SAR) use as input a table in csv format including the values of dependent variable and their coordinates (dependent, $x, y$ ), together with the raster predictor variables. All analyses outputs textual logs including specific statistics (Figure 1). For analyses of spatial patterns, the functions output figures and graphs as well aimed to facilitate interpretation of results (Figure 1). To use BioDinamica, one only needs to install Dinamica-EGO (http://csr.ufmg.br/dinamica/) and the package BioDinamica. Complete documentation is available at (http://csr.ufmg.br/dinamica/dokuwiki/doku.php?id=biodinamica) and online discussion list for questions and bugs at (https://groups.google.com/forum/\#!forum/dinamica-ego). The online supplementary material of BioDinamica comes with BioDinamica installation guide and a guide that provides a brief explanation of its functions.

\section{Mapping spatial biodiversity patterns}

BioDinamica includes several functions for spatial analyses of diversity patterns, such as beta-diversity, phylogenetic beta-diversity, endemicity, species richness, phylodiversity, and phylogenetic endemism. All these functions employ hexagonal tiles (equal area hexagons) as sample units, but also allow continuous interpolating of point data by using spatially explicit models. The interpolation models available in BioDinamica are the Spline method that derives a smooth prediction curve as a function of distance from observed points, nearest neighbour and the kriging, which applies a spatial interpolation according to a variogram distribution. Also available are analyses that predict spatial patterns (e.g. species richness, endemicity, phylodiversity) using predictor variables (e.g. climate variables) through generalized linear models (GLM), spatial autoregressive models (SAR), and universal kriging

Analyses of beta-diversity and phylogenetic beta-diversity patterns allow beta-diversity partitioning into two components, turnover and nestedness. These components can be represented by using either hexagonal tiles or continuous interpolation in order to visualize the spatial variation of each component. To map beta-diversity patterns, we have implemented GDM (Ferrier et al., 2007). This model predicts the beta-diversity patterns by using environmental predictors. Our implementation of GDM also allows applying the beta-diversity model to scenario modelling (past, or future, for example). Some diversity variables are more affected by sampling density and bias, such as species richness (Oliveira et al., 2016). To cope with that, we have implemented a rarefaction technique (Oliveira et al., 2019) that allows quantifying the relative richness between areas by standardizing sampling effort.

\section{Implementation of new methods}

We also included novel analytical methods in BioDinamica. The Geographic Interpolation of Endemism (GIE) method identifies areas of endemism (AoE) (Oliveira, Brescovit \& Santos, 2015). This method had not yet been fully implemented into a single integrated software environment. Hence, our GIE

PeerJ reviewing PDF | (2018:11:32602:1:1:CHECK 25 May 2019) 
122

123

124

125

126

127

128

129

130

131

132

133

134

135

136

137

138

139

140

141

142

143

144

145

146

147

148

149

150

151

152

153

154

155

156

157

158

159

160

161

162

163

implementation needs not additional GIS software. The AoE outputs include raster maps for all scales and consensus, figures with AoE identification, tables describing how many and which species occur in each AoE, and a report with statistical information. This method can be used to identify patterns of congruent distribution among species for testing biogeographic hypotheses, such as vicariance, and for conservation priority studies (e.g. Oliveira et al., 2019).

To identify spatial patterns of beta-diversity, we have implemented a new method named Species Composition Interpolation (SCI) (Oliveira, Vasconcelos \& Santos, 2017). This method spatially interpolates beta-diversity patterns by using values of a NMDS of the beta-diversity index matrix. Our implementation generates a raster map for each axis of the specialized NMDS, and a multiband raster cube for visualization of the axes through a RGB composite. The model also tests the spatial autocorrelation of the values of NMDS, which is a premise for this analysis. As another option, the user can classify the resulting maps into discrete regions (biogeographic regions) through techniques such as the k-means, random forest and CLARA (Cluster for large applications) unsupervised classification (Ade \& Hestir, 2017). The latter technique allows choosing the number of classes, and then the algorithm identifies the intervals of values that best fit that number of classes (Ade \& Hestir, 2017). We have also implemented an analysis analogous to $\mathrm{SCl}$ for phylogenetic beta-diversity and the Phylogenetic composition interpolation (PCI) (Oliveira et al., 2019).

\section{Evolutionary Spatial Patterns}

BioDinamica provides a set of analytical tools for spatial mapping of evolutionary patterns. Using phylogenetic data, it is possible to create maps of phylogenetic beta-diversity (Graham \& Fine, 2008), phylogenetic diversity, phylogenetic endemism (Rosauer et al., 2009), and to plot phylogenies on a map by using spatial interpolation. These analyses enable the user to map the evolutionary patterns of the groups studied in the geographic space, being useful for testing evolutionary hypotheses such as vicariance and dispersion across space. In addition, we have implemented the Phylogenetic generalized dissimilarity model (Phylo-GDM) (Rosauer et al., 2014). Finally, BioDinamica enables to perform scenario projections based on phylogenies analyses by using predictor interpolation (GLM, LM and SAR).

\section{Species Distribution models}

Today, species distribution models (SDM) are one of the most widely used biogeographic tools. We have implemented a set of SDM in BioDinamica (Bioclim, Boosted Regression Trees - BRT, Classification and regression trees - CART, Generalized Additive Models - GAM, Gradient boosting model - GBM, Generalized linear model - GLM, Mixture discriminant analysis - MDA, Multivariate adaptive regression splines - MARS, Recursive partitioning for classification trees - RPART, Maxlike - a maximum entropy tool-, MAXENT, Random forest - RF and Support vector machines - SVM). In addition to SDMs, we have developed a set of ancillary tools for pre-processing and post-processing SDM inputs and outputs. These analyses allow modelling distribution of species by means of predictor variables (environmental variables). There is a wide range of uses for these models, from setting priorities for biodiversity conservation to testing of biogeographic and evolutionary hypotheses, such as events of niche divergence. In addition to SDMs themselves, we have created a set of tools for pre-processing and post-processing SDMs' inputs and outputs. For pre-processing, we have implemented two ways of creating pseudoabsences: the traditional one, which draws random points out of the presence samples of the species; and another based on sample evidence. The pseudo-absences based on sample evidence are obtained by sampling the pseudo-absences in the best-sampled regions (by using a kernel density map of sampling).

PeerJ reviewing PDF | (2018:11:32602:1:1:CHECK 25 May 2019) 
164 In this way, the user provides occurrence points for the study group of species and the function generates 165 a sampling effort map. From this map, the model draws samples (pseudoabsences) for areas more densely 166 sampled. This technique is based on a simple premise: there is a greater probability that an absence is 167 true when a well-sampled area (for a given taxonomic group) does not show occurrences of a particular 168 species. In addition, various techniques for data validation and partitioning come with the SDMs package 169 (table 1).

\section{Interpolation}

171 BioDinamica provides two forms of spatial interpolation: interpolation based on spatial data structure 172 (spline, nearest neighbour and kriging); and statistical interpolation using predictive models (GLM, LM, 173 SAR, GWR and universal kriging). Several biodiversity environmental data sets have an irregular spatial 174 distribution and hence sampling gaps. To cope with that, spatial interpolation is used to produce 175 continuous surfaces of these phenomena. For example, by using the Spline and Kriging spatial 176 interpolation tools, we can interpolate continuous variables based only on their spatial autocorrelation 177 structure as a predictor. For more complex problems, and where there is information on possible 178 predictors, we can interpolate the spatial distribution by using generalized linear models (GLM). In addition to these methods, we have implemented hybrid models that employ the spatial structure of the predictive variables (Spatial autoregressive model: SAR). The BioDinamica analyses of biodiversity patterns (species richness, phylodiversity, endemicity, beta-diversity and phylogenetic beta-diversity) interpolate results by using either spline, nearest neighbour or kriging as an option. In addition, these patterns can also be interpolated by predictive models (GLM, SAR and universal kriging). The spatial and predictive interpolation techniques can be employed to test a wide range of biogeographic hypotheses, such as tests of patterns in biodiversity, as well as a means of filling in sampling gaps for biogeographic analyses.

187

\section{Statistical and Ordination}

Statistical analysis and ordering are central to biogeography and macroecology. To validate predictive models (such as SDM), we have built a binary map validation function. This function performs tests for accuracy, precision, sensitivity, specificity, Kappa and true skill statistics (TSS). For continuous value maps, we have included the area under the curve (AUC). For the analysis of spatial patterns, we have included the analysis of Moran I and the Spatial Variogram.

One common problem in spatial modelling (including SDMs) is the high correlation between variables. To analyse the correlation between raster maps, BioDinamica includes a map correlation test and the Clustering of Variables analysis (Chavent et al., 2012). Another strategy to avoid correlation between predictor variables is by means of principal component analysis (PCA). In BioDinamica, we have implemented a function that creates a raster cube of the axes of PCA. These raster maps can be used as predictors because while they still represent the original variables, there is no more correlation between them. In order to use PCA raster in models designed for scenario projection (such as climate change scenarios), we have included the PCA projection option. This option employs the PCA model generated with the current variables to produce a PCA raster under a different scenario from the one whereby the variables were generated. Another implemented ordering technique produces raster maps of axes that are free of correlation assigning different weights to the variables to maximize their predictive ability. These ordination methods are principal component regression (PCR); partial least squares regression (PLSR); and canonical powered partial least square (CPPLS). In all of these techniques, the option of 
206

207

208

209

210

211

212

213

214

215

216

217

218

219

220

221

222

223

224

225

226

227

228

229

230

231

232

233

234

235

236

237

238

239

240

241

242

243

244

245

projection is available for scenario modelling. The raster maps generated from PCA, PCR and PLSR can be used as substitutes for the predictive variables in analyses in which the dependent variable has continuous values. The raster generated from PCA and CPPLS can be used as predictor variables in analyses in which the dependent variable has discrete values. Furthermore, we have implemented spatialization by nonmetric multidimensional scaling NMDS. This function can be used to spatialize genetic data (genetic, phylogenetic or phylogeographic distance matrix) or even morphometric data (by the morphological distance matrix).

\section{General Tools}

BioDinamica provides a set of general tools for biogeography and macroecology analyses in an integrated modelling environment. In general, techniques employed in biogeographic analyses are only available as a series of standalone procedures in GIS software. For example, it is often necessary to cross-tabulate explanatory variables (such as climatic data) with species occurrence locations. BioDinamica "Extract values to points" function does this easily. In addition, the function "Create sample points" transforms binary maps (such as the ones from species distribution models) into occurrence points that can be input directly into other BioDinamica analytical tools.

\section{Proof of concept}

For exemplifying the potential of BioDinamica, we use the software to explore three patterns of bird diversity in the Amazon: beta-diversity, species richness, and endemism by using as input the distribution polygons of bird species from Birdlife International (http://www.birdlife.org). Oliveira, Vasconcelos \& Santos (2017) have already explored biogeographic patterns of Amazonian birds using museum data. Here, we test the congruence of beta-diversity patterns as observed in Oliveira, Vasconcelos \& Santos (2017) with those obtained from using occurrence polygons from the aforementioned dataset. We also investigate other bird geographical patterns (richness and index of endemism), which were not explored by Oliveira, Vasconcelos \& Santos (2017). In addition, we investigate the use of predictive models based on environmental variables (GLM and GDM) to spatially predict these biodiversity patterns.

The polygons of species distribution are converted into sample points through the function "Create samples" in BioDinamica by using 500 regular points per species. Points outside of the study area are ignored. We employ 179,188 records of 446 species of birds endemic to the Amazon. To spatially interpolate the sample data, we apply "Species composition interpolation" (SCl), "Species richness interpolation" (SR) and "Endemism by weighing endemism" (WE). All methods consist of spatial interpolation techniques. In addition, we apply "Generalized Dissimilarity model" (GDM) for beta diversity and "Generalized linear model" (GLM) for predicting species richness and endemism (SRM and WEM, respectively). For GDM analysis, we use hexagons as sample units (1 degree side) and the geographic distance from sample units for estimating the effects of the environmental covariates. In GLM, we use the Gaussian distribution for model estimation. In this analysis, we employ all the 19 climatic variables from Wordclim (http://www.worldclim.org/) as environmental predictors. For that, we convert these variables (related to temperature and rainfall) into axes of a principal component analysis (PCA) to remove the correlations between them and to reduce the number of variables. For this, we use only the first four axes of PCA, which account for $\approx 90 \%$ of the variance since they proved statistically significant, i.e. explaining more than expected by chance for the 19 variables (>5.26\%). 
246

Beta-diversity results show spatial patterns very similar to those observed for Amazonian birds through collection data (Oliveira, Vasconcelos \& Santos, 2017). Interpolation (SCI) and prediction using environmental variables (GDM) are quite similar as well (Figure 2). This is stressed by the high explanation of the model given the environmental variables (65\% of explanation). This may indicate that the beta diversity geographic patterns as associated with the water basins of large rivers by Oliveira, Vasconcelos \& Santos (2017) are, in fact, related to climatic conditions throughout the Amazon. Although all of these analyses are relatively complex, they are performed in a relatively short time. In a notebook with a $2.70 \mathrm{GHz}$ Core i7 -7500U dual-core processor and 16GB of RAM, GDM runs in 3 minutes and 42 seconds and $\mathrm{SCl}$ in 27 minutes and 44 seconds.

The analysis of species richness outputs different results between using techniques of interpolation and prediction by GLM (Figure 2). This can be caused by the low predictive capacity of the explanatory variables (climatic variables). The richness patterns resulting from interpolation (Figure $2 \mathrm{c}$ ) are very similar to those from analyses that only employ the distribution polygons of the species (see https://biodiversitymapping.org/wordpress/index.php/birds/). Thus, similarity between interpolated results with those observed in the polygon data, together with a large difference between interpolated results and the geographical distribution of environmental predictors, may indicate a low predictive power of the environmental variables for mapping bird richness patterns in the Amazon. The interpolated results more closely resemble the raw data from Birdlife International. However, this type of analysis requires validation using independent data to determine which patterns best reflect reality. The interpolation of species richness runs in 7 minutes and 50 seconds and the prediction by GLM in 4 minutes and 23 seconds.

The patterns of endemism (WE index) are consistent with that observed by Oliveira, Vasconcelos \& Santos (2017) for areas of endemism. The areas identified with the highest number of species of most restricted distribution (Figure 2) are coincident with the endemism areas identified by aforementioned authors who used a different set of data. However, we must be cautious with these similarities, since the patterns of endemicity (WE) are not necessarily congruent with the areas of endemism. Interpolation via WE runs in 15 minutes and 18 seconds and the prediction through GLM in 16 minutes.

The short computer time demonstrates the efficiency of BioDinamica in processing large datasets. In addition, BioDinamica allows compressing the dimensionality of predictor variables through the "PCA function". Many other biogeographic patterns analyses are also doable using this same dataset and other BioDinamica functions, such as GIE, phylogenetic endemism, phylogenetic beta diversity, etc. This in turn demonstrates the software versatility in exploring geographical patterns of biological data.

\section{Wizard: a tutorial interface}

All the functions of BioDinamica are available as graphical operators of Dinamica-EGO. In addition, we provide model examples containing wizard tutorial. In this way, the user is guided through an illustrated tutorial that helps setting up and running the BioDinamica functions. Not only wizard tutorial illustrates applications, it also facilitates access to literature references (Figure 1). Lastly, BioDinamica installation comes with sample datasets for training. Also available is an online guidebook with a comprehensive tutorial on Bll BioDinamica functions http://csr.ufmg.br/dinamica/dokuwiki/doku.php?id=biodinamica).

\section{Conclusions}

PeerJ reviewing PDF | (2018:11:32602:1:1:CHECK 25 May 2019) 
287 BioDinamica encompasses a wide variety of tools for spatial analyses of biodiversity, biogeography, 288 macroecology and evolution. Developed using Dinamica-EGO freeware, BioDinamica delivers high 289 performance on a user-friendly interface. In particular, the Dinamica-EGO platform allows the use of all 290 functions into more complex models that includes loops, iterations and bifurcation pipelines. In this way, 291 the BioDinamica functions become components of advanced models for conservation analyses and 292 environmental simulations developed by using EGO graphical programming language.

295 Acknowledgments

296 We thank Adalberto J. Santos, Ignacio Avila, Leonardo Sousa Carvalho, Marcelo Leandro Bueno, William Leles de Souza Costa for ideas, motivation and testing BioDinamica. 


\section{References}

Ade C, Hestir E. 2017. Remote sensing and Gls for ecologists: using open source software. Photogrammetric Engineering \& Remote Sensing 83:391-392. DOI: 10.14358/PERS.83.6.391.

Chavent M, Kuentz-Simonet V, Liquet B, Saracco J. 2012. ClustOfVar : An R Package for the Clustering of Variables. Journal of Statistical Software 50:1-16. DOI: 10.18637/jss.v050.i13.

Donnellan SC, Cook LG. 2009. Phylogenetic endemism : A new approach for identifying geographical concentrations of evolutionary history Phylogenetic endemism : a new approach for identifying geographical concentrations of evolutionary history. DOI: 10.1111/j.1365-294X.2009.04311.x.

Fenker J, Tedeschi LG, Pyron RA, Nogueira CDC. 2014. Phylogenetic diversity, habitat loss and conservation in South American pitvipers (Crotalinae: Bothrops and Bothrocophias ). Diversity and Distributions:n/a-n/a. DOI: 10.1111/ddi.12217.

Ferrier S, Manion G, Elith J, Richardson K. 2007. Using generalized dissimilarity modelling to analyse and predict patterns of beta diversity in regional biodiversity assessment. Diversity and Distributions 13:252-264. DOI: 10.1111/j.1472-4642.2007.00341.x.

Graham CH, Fine PVA. 2008. Phylogenetic beta diversity: linking ecological and evolutionary processes across space in time. Ecology Letters 11:1265-1277. DOI: 10.1111/j.1461-0248.2008.01256.x.

Graham CH, Hijmans RJ. 2006. A comparison of methods for mapping species ranges and species richness. Global Ecology and Biogeography 15:578-587. DOI: 10.1111/j.1466-822x.2006.00257.x.

Hinchliff CE, Smith SA, Allman JF, Burleigh JG, Chaudhary R, Coghill LM, Crandall KA, Deng J, Drew BT, Gazis R, Gude K, Hibbett DS, Katz LA, Laughinghouse HD, McTavish EJ, Midford PE, Owen CL, Ree $\mathrm{RH}$, Rees JA, Soltis DE, Williams T, Cranston KA. 2015. Synthesis of phylogeny and taxonomy into a comprehensive tree of life. Proceedings of the National Academy of Sciences 112:12764-12769. DOI: $10.1073 /$ pnas.1423041112.

Ladle RJ, Malhado ACM, Correia RA, Santos JG, Santos AMC. 2015. Research trends in biogeography. Journal of Biogeography 42:2270-2276. DOI: 10.1111/jbi.12602.

Mcgoogan K, Kivell T, Hutchison M, Young H, Blanchard S, Keeth M, Lehman SM. 2007. Phylogenetic diversity and the conservation biogeography of African primates. :1962-1974. DOI: 10.1111/j.1365-2699.2007.01759.x.

Oliveira U, Brescovit AD, Santos AJ. 2015. Delimiting Areas of Endemism through Kernel Interpolation. PLOS ONE 10:e0116673. DOI: 10.1371/journal.pone.0116673.

Oliveira U, Paglia AP, Brescovit AD, de Carvalho CJB, Silva DP, Rezende DT, Leite FSF, Batista JAN, Barbosa JPPP, Stehmann JR, Ascher JS, de Vasconcelos MF, De Marco P, Löwenberg-Neto P, Dias PG, Ferro VG, Santos AJ. 2016. The strong influence of collection bias on biodiversity knowledge shortfalls of Brazilian terrestrial biodiversity. Diversity and Distributions 22:1232-1244. DOI: 10.1111/ddi.12489.

Oliveira U, Soares-Filho BS, Santos AJ, Paglia AP, Brescovit AD, de Carvalho CJB, Silva DP, Rezende DT, Leite FSF, Batista JAN, Barbosa JPPP, Stehmann JR, Ascher JS, Vasconcelos MF, Marco P De, Löwenberg-Neto P, Ferro VG. 2019. Modelling Highly Biodiverse Areas in Brazil. Scientific Reports 9:6355. DOI: 10.1038/s41598-019-42881-9. 
338

339

340

341

342

343

344

345

346

347

348

349

350

351

352

353

354

355

356

357

358

359

360

361

362
Oliveira U, Vasconcelos MF, Santos AJ. 2017. Biogeography of Amazon birds: rivers limit species composition, but not areas of endemism. Scientific Reports 7:2992. DOI: 10.1038/s41598-01703098-w.

Rosauer DF, Ferrier S, Williams KJ, Manion G, Keogh JS, Laffan SW. 2014. Phylogenetic generalised dissimilarity modelling: a new approach to analysing and predicting spatial turnover in the phylogenetic composition of communities. Ecography 37:21-32. DOI: 10.1111/j.16000587.2013.00466.x.

Rosauer D, Laffan SW, Crisp MD, Donnellan SC, Cook LG. 2009. Phylogenetic endemism: a new approach for identifying geographical concentrations of evolutionary history. Molecular Ecology 18:40614072. DOI: 10.1111/j.1365-294X.2009.04311.x.

Vilhena DA, Antonelli A. 2015. delimiting biogeographical regions. Nature Communications 6:1-9. DOI: $10.1038 /$ ncomms7848.

Whittaker RJ, Araújo MB, Jepson P, Ladle RJ, Watson JEM, Willis KJ. 2005. Conservation biogeography: Assessment and prospect. Diversity and Distributions 11:3-23. DOI: 10.1111/j.13669516.2005.00143.x.

Figure 1: Graphical interface, a: Interface; b: inputs and c: outputs of BioDinamica operators.

Figure 2: Amazonian bird diversity patterns based on Birdlife International data analysed through BioDinamica functions. a: species composition interpolated by nearest neighbour, RGB represents the three axes of NMDS and b: predicted by GDM; c: species richness interpolated by nearest neighbour and d predicted by GLM; e: Weight endemism index corrected interpolated and f: predicted by GLM.

Table 1: Description of main functions, inputs and outputs of BioDinamica 


\section{Table 1 (on next page)}

Description of main functions

Description of main functions, inputs and outputs of BioDinamica 
1 Table 1: Description of main functions, inputs and outputs of BioDinamica

\begin{tabular}{|c|c|c|c|c|c|}
\hline Tool group & Function name & Function & Inputs & Outputs & Reference \\
\hline Biogeography & $\begin{array}{c}\text { GIE - Geographic Interpolation } \\
\text { of Endemism }\end{array}$ & Identify Areas of Endemism & $\begin{array}{l}\text { Species points of occurence, } \\
\text { map of study area }\end{array}$ & $\begin{array}{l}\text { Raster maps, figures } \\
\text { and reports }\end{array}$ & $\begin{array}{l}\text { Oliveira U, Brescovit AD, } \\
\text { Santos AJ. 2015. Delimiting } \\
\text { Areas of Endemism } \\
\text { through Kernel } \\
\text { Interpolation. PloS one } \\
\text { 10:e0116673. }\end{array}$ \\
\hline Biogeography & $\begin{array}{l}\mathrm{SCl} \text { - Species Composition } \\
\text { Interpolation }\end{array}$ & $\begin{array}{l}\text { Map beta-diversity and map } \\
\text { partitions of beta-diversity } \\
\text { (turnover and nestedness) }\end{array}$ & $\begin{array}{l}\text { Species points of occurence, } \\
\text { map of study area }\end{array}$ & $\begin{array}{l}\text { Raster maps, figures } \\
\text { and reports }\end{array}$ & $\begin{array}{c}\text { Oliveira U, Vasconcelos MF, } \\
\text { Santos AJ. } 2017 . \\
\text { Biogeography of Amazon } \\
\text { birds: rivers limit species } \\
\text { composition, but not areas } \\
\text { of endemism. Scientific } \\
\text { Reports 7:2992. } \\
\end{array}$ \\
\hline Biogeography & $\begin{array}{l}\mathrm{PCl} \text { - Phylogenetic Composition } \\
\text { Interpolation }\end{array}$ & $\begin{array}{c}\text { Map phylogenetic beta-diversity } \\
\text { and map partitions of beta- } \\
\text { diversity (turnover and } \\
\text { nestedness) }\end{array}$ & $\begin{array}{c}\text { Species points of occurence, } \\
\text { phylogenetic tree, map of } \\
\text { study area }\end{array}$ & $\begin{array}{l}\text { Raster maps, figures } \\
\text { and reports }\end{array}$ & \multirow{3}{*}{$\begin{array}{l}\text { Oliveira U, et al. } 2019 . \\
\quad \text { Modelling Highly } \\
\text { Biodiverse Areas in Brazil. } \\
\text { Scientific Reports 9:6355. }\end{array}$} \\
\hline Biogeography & $\begin{array}{l}\text { SR - Species richness } \\
\text { interpolation }\end{array}$ & Map species richness & $\begin{array}{c}\text { Species points of occurence, } \\
\text { map of study area }\end{array}$ & $\begin{array}{l}\text { Raster maps, figures } \\
\text { and reports }\end{array}$ & \\
\hline Biogeography & $\begin{array}{l}\text { RSR - Resampling of species } \\
\text { richness interpolation }\end{array}$ & $\begin{array}{c}\text { Resampling data for reduce } \\
\text { effect of sampling differences to } \\
\text { map species richness }\end{array}$ & $\begin{array}{l}\text { Species points of occurence, } \\
\text { map of study area }\end{array}$ & $\begin{array}{l}\text { Raster maps, figures } \\
\text { and reports }\end{array}$ & \\
\hline Biogeography & $\begin{array}{l}\text { GDM - Generalized Dissimilarity } \\
\text { Model }\end{array}$ & $\begin{array}{l}\text { Map beta-diversity by } \\
\text { environmental predictors }\end{array}$ & $\begin{array}{l}\text { Species points of occurence, } \\
\text { map of study area and } \\
\text { rasters of environmental } \\
\text { predictors }\end{array}$ & $\begin{array}{l}\text { Raster maps, figures } \\
\text { and reports }\end{array}$ & $\begin{array}{c}\text { Ferrier S, Manion G, Elith J, } \\
\text { Richardson K. 2007. Using } \\
\text { generalized dissimilarity } \\
\text { modelling to analyse and } \\
\text { predict patterns of beta } \\
\text { diversity in regional } \\
\text { biodiversity assessment. } \\
\text { Diversity and Distributions } \\
\text { 13:252-264. }\end{array}$ \\
\hline Biogeography & $\begin{array}{l}\text { Phylo-GDM - Phylogenetic } \\
\text { Generalized Dissimilarity Model }\end{array}$ & $\begin{array}{l}\text { Map phylogenetic beta-diversity } \\
\text { by environmental predictors }\end{array}$ & $\begin{array}{l}\text { Species points of occurence, } \\
\text { phylogenetic tree, map of } \\
\text { study area and rasters of } \\
\text { environmental predictors }\end{array}$ & $\begin{array}{l}\text { Raster maps, figures } \\
\text { and reports }\end{array}$ & $\begin{array}{c}\text { Rosauer DF, Ferrier S, } \\
\text { Williams KJ, Manion G, } \\
\text { Keogh JS, Laffan SW. } 2014 . \\
\text { Phylogenetic generalised } \\
\text { dissimilarity modelling: a } \\
\text { new approach to analysing } \\
\text { and predicting spatial } \\
\text { turnover in the } \\
\text { phylogenetic composition } \\
\text { of communities. Ecography } \\
\text { 37:21-32. }\end{array}$ \\
\hline Biogeography & $\begin{array}{l}\text { PD - Phylogenetic Diversity } \\
\text { Interpolation }\end{array}$ & Map phylogenetic diversity & $\begin{array}{c}\text { Species points of occurence, } \\
\text { phylogenetic tree and map } \\
\text { of study area }\end{array}$ & $\begin{array}{l}\text { Raster maps, figures } \\
\text { and reports }\end{array}$ & $\begin{array}{c}\text { Oliveira U, et al. } 2019 . \\
\text { Modelling Highly } \\
\text { Biodiverse Areas in Brazil. } \\
\text { Scientific Reports 9:6355. } \\
\end{array}$ \\
\hline Biogeography & WE - Weight Endemism & $\begin{array}{c}\text { Map of Weight endemism index } \\
\text { by cell }\end{array}$ & $\begin{array}{l}\text { Species points of occurence, } \\
\text { map of study area }\end{array}$ & $\begin{array}{l}\text { Raster maps, figures } \\
\text { and reports }\end{array}$ & $\begin{array}{c}\text { Williams PH, Humphries CJ. } \\
\text { 1994. Biodiversity, } \\
\text { taxonomic relatedness, and } \\
\text { endemism in conservation. } \\
\text { Oxford: Oxford University } \\
\text { Press. } \\
\end{array}$ \\
\hline Biogeography & $\begin{array}{l}\text { PE - Phylogenetic Weight } \\
\text { Endemism }\end{array}$ & $\begin{array}{l}\text { Map of phylogenetic Weight } \\
\text { endemism index by cell }\end{array}$ & $\begin{array}{l}\text { Species points of occurence, } \\
\text { phylogenetic tree and map } \\
\text { of study area }\end{array}$ & $\begin{array}{l}\text { Raster maps, figures } \\
\text { and reports }\end{array}$ & $\begin{array}{c}\text { Rosauer D, Laffan SW, Crisp } \\
\text { MD, Donnellan SC, Cook } \\
\text { LG. 2009. Phylogenetic } \\
\text { endemism: a new } \\
\text { approach for identifying } \\
\text { geographical } \\
\text { concentrations of } \\
\text { evolutionary history. } \\
\text { Molecular Ecology } \\
\text { 18:4061-4072. }\end{array}$ \\
\hline Biogeography & PS - Phylogenetic Spatialization & Map phylogentic information & $\begin{array}{c}\text { Species points of occurence, } \\
\text { phylogenetic tree and map } \\
\text { of study area }\end{array}$ & $\begin{array}{l}\text { Raster maps, figures } \\
\text { and reports }\end{array}$ & \\
\hline Biogeography & SRM - Species richness Model & $\begin{array}{c}\text { Map species richness by model } \\
\text { prediction (GLM, SAR, Universal } \\
\text { Kriging) }\end{array}$ & $\begin{array}{c}\text { Species points of occurence, } \\
\text { map of study area and } \\
\text { rasters of environmental } \\
\text { predictors }\end{array}$ & $\begin{array}{l}\text { Raster maps, figures } \\
\text { and reports }\end{array}$ & $\begin{array}{l}\text { adapted from: } \\
\text { Oliveira U, et al. } 2019 . \\
\text { Modelling Highly } \\
\text { Biodiverse Areas in Brazil. }\end{array}$ \\
\hline Biogeography & $\begin{array}{l}\text { RSRM - Resampling of species } \\
\text { richness Model }\end{array}$ & $\begin{array}{l}\text { Resampling data for reduce } \\
\text { effect of sampling differences to } \\
\text { map species richness and } \\
\text { predict values by model (GLM, } \\
\text { SAR, Universal Kriging) }\end{array}$ & $\begin{array}{l}\text { Species points of occurence, } \\
\text { map of study area and } \\
\text { rasters of environmental } \\
\text { predictors }\end{array}$ & $\begin{array}{l}\text { Raster maps, figures } \\
\text { and reports }\end{array}$ & Scientific Reports 9:6355. \\
\hline
\end{tabular}




\begin{tabular}{|c|c|c|}
\hline Biogeography & $\begin{array}{c}\text { PDM - Phylogenetic Diversity } \\
\text { Model }\end{array}$ & $\begin{array}{c}\text { Map phylogenetic diversity by } \\
\text { model prediction (GLM, SAR, } \\
\text { Universal Kriging) }\end{array}$ \\
\hline Biogeography & $\begin{array}{c}\text { WEM - Weight Endemism } \\
\text { Model }\end{array}$ & $\begin{array}{c}\text { Map weight endemism index by } \\
\text { model prediction (GLM, SAR, } \\
\text { Universal Kriging) }\end{array}$ \\
\hline
\end{tabular}

Species points of occurence, map of study area and rasters of environmental predictors

Species points of occurence, map of study area and rasters of environmental predictors

\author{
Raster maps, figures \\ and reports
}

Raster maps, figures
and reports

adapted from:

Williams $\mathrm{PH}$, Humphries $\mathrm{CI}$. 1994. Biodiversity, taxonomic relatedness, and endemism in conservation. Oxford: Oxford University Press. adapted from: Rosauer D, Laffan SW, Crisp MD, Donnellan SC, Cook LG. 2009. Phylogenetic Map phylogenetic weight Species points of occurence

\begin{abstract}
endemism index by model prediction (GLM, SAR, Universal Kriging)

Endemism model

Biogeography
\end{abstract}

\begin{tabular}{lcc}
\hline Biogeography & Sampling Effort & Map density of samples \\
\hline Biogeography & SDM - Species Distribution \\
Models & $\begin{array}{c}\text { Modeling species distribution by } \\
\text { environmental predictors and } \\
\text { several algorithms of SDM }\end{array}$
\end{tabular}
several algorithms of SDM map of study area and rasters of environmental predictors
Raster maps, figures and reports
Sampling points and map of Raster maps and study area endemism: a new

approach for identifying geographical concentrations of evolutionary history. Molecular Ecology 18:4061-4072 Oliveira U, et al. 2019. Modelling Highly Biodiverse Areas in Brazil. Scientific Reports 9:6355. Elith J, Leathwick JR. 2009. Species Distribution Models: Ecological

Raster maps, figures
and reports
and reports

Explanation and Prediction Across Space and Time.
Species points of occurence, map of study area and rasters of environmental predictors Annual Review of Ecology, Evolution, and Systematics 40:677-697.

Broennimann O, et al. 2012. Measuring ecological niche overlap from occurrence and spatial environmental. :481-497.

\begin{tabular}{|c|c|c|c|c|c|}
\hline Biogeography & Niche overlap & $\begin{array}{c}\text { Test niche overlap by SDM } \\
\text { rasters }\end{array}$ & SDM rasters & Report table & $\begin{array}{l}\text { Broennimann } 0 \text {, et al. } \\
\text { 2012. Measuring ecological } \\
\text { niche overlap from } \\
\text { occurrence and spatial } \\
\text { environmental. :481-497. }\end{array}$ \\
\hline Biogeography & Minimum Convex Hull & $\begin{array}{l}\text { Create minimum convex hulll } \\
\text { polygon }\end{array}$ & $\begin{array}{l}\text { Species points of occurence, } \\
\text { map of study area }\end{array}$ & Raster maps & - \\
\hline SDM tool & AUC - Area Under Curve & $\begin{array}{c}\text { Calculate Area Under Curve } \\
\text { statistic }\end{array}$ & $\begin{array}{l}\text { Species points of occurence } \\
\text { (presence and absence), } \\
\text { raster with continuous } \\
\text { values (SDM for instance) }\end{array}$ & Reports & $\begin{array}{l}\text { Hanley, James A.; McNeil, } \\
\text { Barbara J. 1982. "The } \\
\text { Meaning and Use of the } \\
\text { Area under a Receiver } \\
\text { Operating Characteristic } \\
\text { (ROC) Curve". Radiology. } \\
\text { 143 (1): 29-36. }\end{array}$ \\
\hline SDM tool & $\begin{array}{l}\text { Statistic for validation of Binary } \\
\text { maps }\end{array}$ & $\begin{array}{l}\text { Calculate precision, sensitivity, } \\
\text { Kappa Cohen, Accuracy, } \\
\text { Specificity and True Skill Statistic } \\
\text { (TSS) }\end{array}$ & $\begin{array}{l}\text { Species points of occurence } \\
\text { (presence and absence), } \\
\text { raster with binary values } \\
\text { (SDM with threshold for } \\
\text { instance) }\end{array}$ & Reports & $\begin{array}{l}\text { Stehman, Stephen V. } 1997 . \\
\text { "Selecting and interpreting } \\
\text { measures of thematic } \\
\text { classification accuracy". } \\
\text { Remote Sensing of } \\
\text { Environment. } 62 \text { (1): 77- } \\
89 . \\
\end{array}$ \\
\hline SDM tool & Create Point samples & $\begin{array}{l}\text { Create points based on binary } \\
\text { maps. Convert SDM maps in } \\
\text { poits of occurence for other } \\
\text { analyses in BioDinamica }\end{array}$ & $\begin{array}{l}\text { Species points of occurence } \\
\text { (presence and absence), } \\
\text { raster with binary values } \\
\text { (SDM with threshold for } \\
\text { instance) }\end{array}$ & Table & - \\
\hline SDM tool & Sum of Maps & $\begin{array}{c}\text { Calculate sum of maps in a } \\
\text { folder }\end{array}$ & $\begin{array}{l}\text { Folder with rasters (SDM } \\
\text { binary, for example) }\end{array}$ & Rasters & - \\
\hline SDM tool & Calculate area of Distributions & $\begin{array}{l}\text { Calculate area of distributions } \\
\text { based on binary maps of SDM }\end{array}$ & $\begin{array}{l}\text { Raster with binary values } \\
\text { (SDM with threshold for } \\
\text { instance) }\end{array}$ & Table & - \\
\hline SDM tool & Extract values to Points & $\begin{array}{l}\text { Create a table with values of } \\
\text { maps (rasters) based on spatial } \\
\text { position of points }\end{array}$ & CSV with points $(x, y)$ & Table & - \\
\hline SDM tool & $\begin{array}{c}\text { Change Maximum and } \\
\text { Minimum values }\end{array}$ & $\begin{array}{c}\text { Rescale values of rasters to } \\
\text { values between } 0 \text { and } 1\end{array}$ & Raster & Rasters & - \\
\hline $\begin{array}{l}\text { Statistica and } \\
\text { Ordination }\end{array}$ & Correlation & $\begin{array}{l}\text { Calculate correlation between } \\
\text { maps }\end{array}$ & $\begin{array}{l}\text { Folder with rasters to } \\
\text { analysis }\end{array}$ & Reports & - \\
\hline $\begin{array}{l}\text { Statistica and } \\
\text { Ordination }\end{array}$ & Clustering of variables & $\begin{array}{l}\text { Compute sets of variables with } \\
\text { high correlation inside groups } \\
\text { and low correlation betwwen } \\
\text { them }\end{array}$ & $\begin{array}{l}\text { Folder with rasters to } \\
\text { analysis }\end{array}$ & $\begin{array}{l}\text { Reports, tables and } \\
\text { figures }\end{array}$ & $\begin{array}{c}\text { Chavent M, Kuentz- } \\
\text { Simonet V, Liquet B, } \\
\text { Saracco J. } 2012 . \\
\text { ClustOfVar : An R Package } \\
\text { for the Clustering of } \\
\text { Variables. Journal of } \\
\text { Statistical Software } 50: 1-\end{array}$ \\
\hline
\end{tabular}




\begin{tabular}{|c|c|c|c|c|c|}
\hline $\begin{array}{c}\text { Statistica and } \\
\text { Ordination }\end{array}$ & Global Moran I & $\begin{array}{c}\text { Compute Moran I index of } \\
\text { spatial autocorrelation }\end{array}$ & Raster file & Reports & - \\
\hline $\begin{array}{l}\text { Statistica and } \\
\text { Ordination }\end{array}$ & Spatial Variogram & $\begin{array}{l}\text { Create graphic of variogram by } \\
\text { distance }\end{array}$ & Raster file & Figure & - \\
\hline $\begin{array}{l}\text { Statistica and } \\
\text { Ordination }\end{array}$ & Unsupervised Classification & $\begin{array}{l}\text { Classification of rasters in } \\
\text { clusters of pixels based on k- } \\
\text { means, random forest and } \\
\text { Clustering Large Applications }\end{array}$ & $\begin{array}{l}\text { Folder with rasters to } \\
\text { analysis }\end{array}$ & Rasters & $\begin{array}{l}\text { Kaufman, Leonard, and } \\
\text { Peter Rousseeuw. } 1990 . \\
\text { Finding Groups in Data: An } \\
\text { Introduction to Cluster } \\
\text { Analysis. }\end{array}$ \\
\hline $\begin{array}{l}\text { Statistica and } \\
\text { Ordination }\end{array}$ & $\begin{array}{c}\text { PCA - Principal Component } \\
\text { Analysis }\end{array}$ & $\begin{array}{c}\text { Create rasters with axis of PCA } \\
\text { based on variables (in raster } \\
\text { format) }\end{array}$ & $\begin{array}{l}\text { Folder with rasters to } \\
\text { analysis }\end{array}$ & Rasters & $\begin{array}{c}\text { Hotelling, H. 1933. Analysis } \\
\text { of a complex of statistical } \\
\text { variables into principal } \\
\text { components. Journal of } \\
\text { Educational Psychology, 24, } \\
417-441\end{array}$ \\
\hline $\begin{array}{l}\text { Statistica and } \\
\text { Ordination }\end{array}$ & $\begin{array}{l}\text { PCA project- Principal } \\
\text { Component Analysis for } \\
\text { projection }\end{array}$ & $\begin{array}{l}\text { Create rasters with axis of PCA } \\
\text { based on variables (in raster } \\
\text { format) and project to another } \\
\text { scenario }\end{array}$ & $\begin{array}{l}\text { Folder with rasters to } \\
\text { analysis and folder with } \\
\text { rasters for projection }\end{array}$ & Rasters & $\begin{array}{c}\text { Hotelling, H. 1933. Analysis } \\
\text { of a complex of statistical } \\
\text { variables into principal } \\
\text { components. Journal of } \\
\text { Educational Psychology, 24, } \\
417-441\end{array}$ \\
\hline $\begin{array}{l}\text { Statistica and } \\
\text { Ordination }\end{array}$ & $\begin{array}{c}\text { PCR - Principal Component } \\
\text { Regression }\end{array}$ & $\begin{array}{c}\text { Create rasters with axis of PCR } \\
\text { analysis based on variables (in } \\
\text { raster format) }\end{array}$ & $\begin{array}{l}\text { CSV table with input points } \\
\text { (samples) with value of } \\
\text { dependent variable } \\
\text { (continuous values) and } \\
\text { folder with rasters to } \\
\text { analysis }\end{array}$ & Rasters & $\begin{array}{l}\text { Jolliffe, lan T. 1982. "A note } \\
\text { on the Use of Principal } \\
\text { Components in } \\
\text { Regression". Journal of the } \\
\text { Royal Statistical Society, } \\
\text { Series C. } 31 \text { (3): 300-303. }\end{array}$ \\
\hline $\begin{array}{l}\text { Statistica and } \\
\text { Ordination }\end{array}$ & $\begin{array}{c}\text { PCR project- Principal } \\
\text { Component Regression for } \\
\text { projection }\end{array}$ & $\begin{array}{l}\text { Create rasters with axis of PCR } \\
\text { analysis based on variables (in } \\
\text { raster format) and project to } \\
\text { another scenario }\end{array}$ & $\begin{array}{l}\text { CSV table with input points } \\
\text { (samples) with value of } \\
\text { dependent variable } \\
\text { (continuous values), folder } \\
\text { with rasters to analysis and } \\
\text { folder with rasters for } \\
\text { projection }\end{array}$ & Rasters & $\begin{array}{l}\text { Jolliffe, lan T. 1982. "A note } \\
\text { on the Use of Principal } \\
\text { Components in } \\
\text { Regression". Journal of the } \\
\text { Royal Statistical Society, } \\
\text { Series C. } 31 \text { (3): 300-303. }\end{array}$ \\
\hline $\begin{array}{l}\text { Statistica and } \\
\text { Ordination }\end{array}$ & $\begin{array}{c}\text { PLSR - Partial Least Squares } \\
\text { Regression }\end{array}$ & $\begin{array}{c}\text { Create rasters with axis of PLSR } \\
\text { analysis based on variables (in } \\
\text { raster format) }\end{array}$ & $\begin{array}{l}\text { CSV table with input points } \\
\text { (samples) with value of } \\
\text { dependent variable } \\
\text { (continuous values) and } \\
\text { folder with rasters to } \\
\text { analysis }\end{array}$ & Rasters & $\begin{array}{l}\text { de Jong, S. 1993. "SIMPLS: } \\
\text { an alternative approach to } \\
\text { partial least squares } \\
\text { regression". Chemometrics } \\
\text { and Intelligent Laboratory } \\
\text { Systems. } 18 \text { (3): 251-263. }\end{array}$ \\
\hline $\begin{array}{l}\text { Statistica and } \\
\text { Ordination }\end{array}$ & $\begin{array}{l}\text { PLSR project- Partial Least } \\
\text { Squares Regression for } \\
\text { projection }\end{array}$ & $\begin{array}{l}\text { Create rasters with axis of PLSR } \\
\text { analysis based on variables (in } \\
\text { raster format) and project to } \\
\text { another scenario }\end{array}$ & $\begin{array}{l}\text { CSV table with input points } \\
\text { (samples) with value of } \\
\text { dependent variable } \\
\text { (continuous values), folder } \\
\text { with rasters to analysis and } \\
\text { folder with rasters for } \\
\text { projection }\end{array}$ & Rasters & $\begin{array}{l}\text { de Jong, S. 1993. "SIMPLS: } \\
\text { an alternative approach to } \\
\text { partial least squares } \\
\text { regression". Chemometrics } \\
\text { and Intelligent Laboratory } \\
\text { Systems. } 18 \text { (3): 251-263. }\end{array}$ \\
\hline $\begin{array}{l}\text { Statistica and } \\
\text { Ordination }\end{array}$ & $\begin{array}{l}\text { CPPLS - Canonical Powered } \\
\text { Partial Least Squares }\end{array}$ & $\begin{array}{l}\text { Create rasters with axis of CPPLS } \\
\text { analysis based on variables (in } \\
\text { raster format) }\end{array}$ & $\begin{array}{l}\text { CSV table with input points } \\
\text { (samples) with value of } \\
\text { dependent variable } \\
\text { (discrete values) and folder } \\
\text { with rasters to analysis }\end{array}$ & Rasters & $\begin{array}{c}\text { Indahl UG, Liland KH, Naes } \\
\text { T. 2009. Canonical partial } \\
\text { least squares-a unified PLS } \\
\text { approach to classification } \\
\text { and regression problems. } \\
\text { Journal of Chemometrics } \\
\text { 23:495-504. } \\
\end{array}$ \\
\hline $\begin{array}{l}\text { Statistica and } \\
\text { Ordination }\end{array}$ & $\begin{array}{c}\text { CPPLS project- Canonical } \\
\text { Powered Partial Least Squares }\end{array}$ & $\begin{array}{l}\text { Create rasters with axis of CPPLS } \\
\text { analysis based on variables (in } \\
\text { raster format) and project to } \\
\text { another scenario }\end{array}$ & $\begin{array}{l}\text { CSV table with input points } \\
\text { (samples) with value of } \\
\text { dependent variable } \\
\text { (discrete values), folder } \\
\text { with rasters to analysis and } \\
\text { folder with rasters for } \\
\text { projection }\end{array}$ & Rasters & $\begin{array}{c}\text { Indahl UG, Liland KH, Naes } \\
\text { T. 2009. Canonical partial } \\
\text { least squares-a unified PLS } \\
\text { approach to classification } \\
\text { and regression problems. } \\
\text { Journal of Chemometrics } \\
\text { 23:495-504. }\end{array}$ \\
\hline
\end{tabular}

\section{2}


Figure 1

\section{Graphical interface}

Graphical interface, a: Interface; b: inputs and c: outputs of BioDinamica operators.
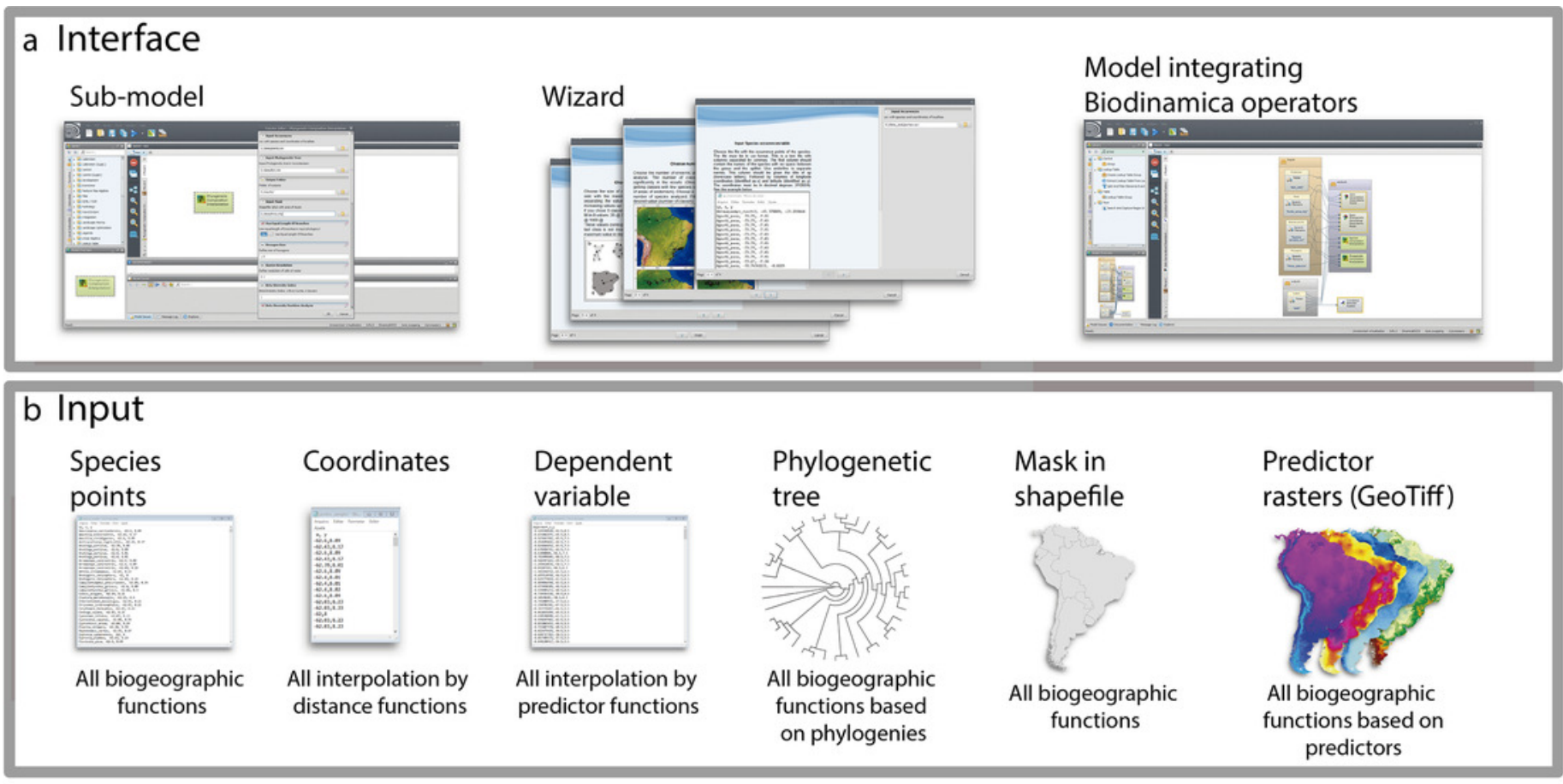

C Output

Raster files (GeoTiff)

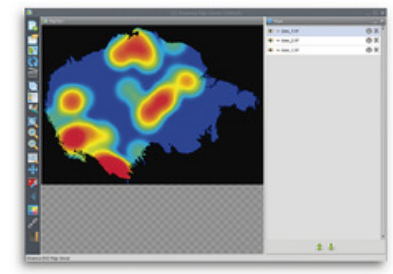

Figures

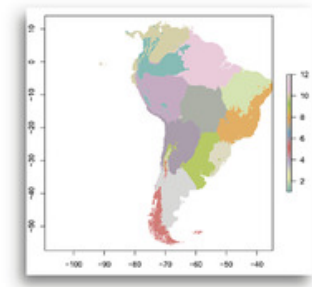

Graphics and reports

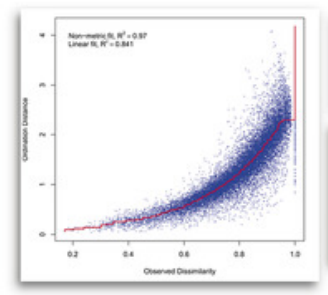

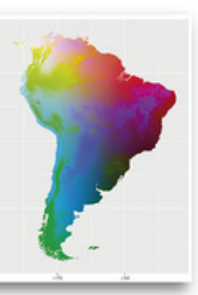

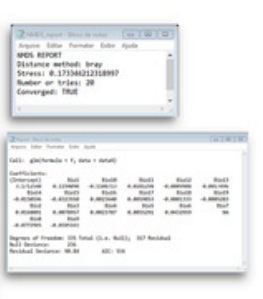




\section{Figure 2}

Amazonian bird diversity patterns based on Birdlife International data

Amazonian bird diversity patterns based on Birdlife International data analysed through

BioDinamica functions. a: species composition interpolated by nearest neighbour, RGB represents the three axes of NMDS and b: predicted by GDM; $c$ : species richness interpolated by nearest neighbour and d predicted by GLM; e: Weight endemism index corrected interpolated and f: predicted by GLM. 

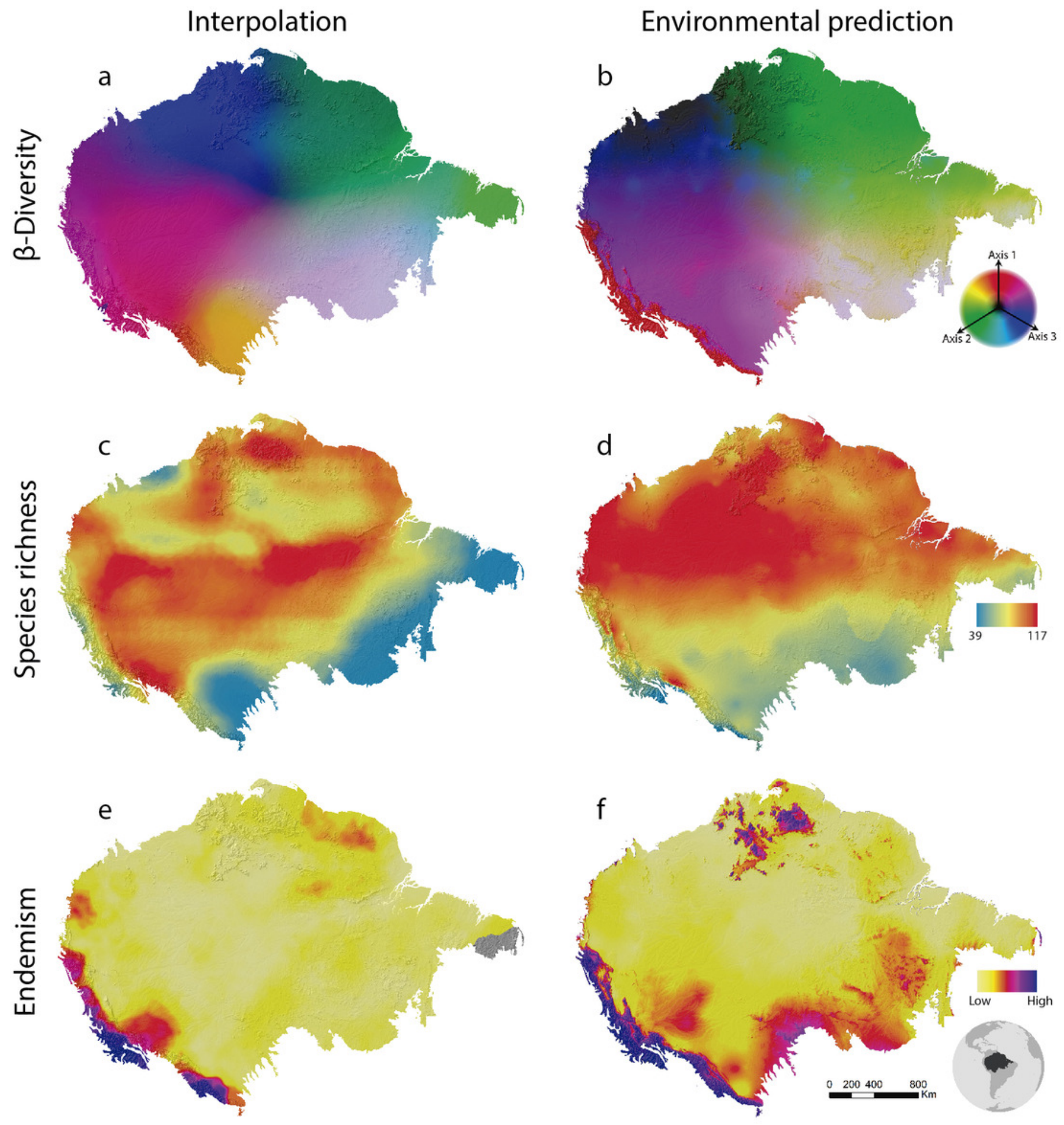